\title{
HAKIKAT MANUSIA MENURUT ISLAM
}

\section{Isop Syafe'i}

Fakultas Psikologi UIN Sunan Gunung Djati Bandung, Jl. A.H Nasution No. 105 Bandung email: isop.syafei@gmail.com

\begin{abstract}
Abstrak
Menurut perspektif filosofis-psikologis, perbedaan pandangan terhadap mansusia menyebabkan menghasilkan corak pendidikan yang beragam. Abdurrahman an-Nahlawi menyatakan bahwa pandangan manusia tentang dirinya akan memberikan dampak yang sangat kuat terhadap sistem pendidikan. ${ }^{1}$ Jika manusia dipandang sebagai makhluk dengan pembawaan dasar jahat, maka pendidikan berarti upaya menekan atau menepis unsur-unsur jahat tersebut. ${ }^{1}$ Jika manusia dipandang sebagai makhluk aktif yang memiliki potensi, minat, dan kemampuan dasar yang baik, maka pendidikan diartikan sebagai proses drawing out yakni mengeluarkan apa yang dimiliki bukan proses pouring in seperti diisinya bejana oleh air.
\end{abstract}

Kata kunci : Hakikat manusia, potensi, kedudukan dan tugas manusia

\section{Abstract}

According psychology-philosophy perspective, various pattern in education caused by different view about human being.. Abdurrahman an-Nahlawi stated that how human view about themselves will give strong effect toward education system. ${ }^{l}$. If human is viewed as creature with an evil talent, then education means as an effort to supress those evil factors. ${ }^{1}$ On the other hands, if human is viewed as an active creature with potential, interest, and good basic competency, education means drawing out process in which taken out everything the children have not pouring in like water jar.

Keywords : Human substance, potential, status and human task

\section{PENDAHULUAN}

Untuk memahami konsep manusia menurut Islam, dapat dipahami bagaimana al-Qur'an memberikan konsep tentang manusia. Menurut Muin Salim, ada dua cara yang dapat digunakan, pertama, dengan menelusuri arti kata-kata yang dipergunakan Al-Qur'an untuk menunjukan makna manusia (analisis terminologis). Kedua, menelusuri pernyataan Al-Qur'an yang berhubungan dengan kedudukan manusia dan potensi yang dimiliki manusia.

Secara terminologis, ungkapan yang dipergunakan Al-Qur'an untuk menunjukan konsep manusia dapat dibedakan atas tiga macam, yaitu : a) alinsan, al-ins, unas, al-nas, anasiy dan insiy; b) al-basyar; dan c) Banu Adam dan zurriyat adam.

a) al-Insan

Secara umum, kata Insan berarti manusia. Dalam al-Qur'an, ungkapan 
yang seakar dengan kata al-Insan dipergunakan kurang lebih sebanyak 331 kali dengan bentuk kata yang berbeda.

\section{TABEL DISTRIBUSI UNGKAPAN INSAN \\ DALAM AL-QUR'AN}

\begin{tabular}{|c|c|c|c|c|}
\hline $\begin{array}{l}\mathbf{N} \\
\mathbf{o .}\end{array}$ & $\begin{array}{l}\text { Ungkapa } \\
\text { n }\end{array}$ & \multicolumn{2}{|c|}{$\begin{array}{l}\text { Pemakaian Pertama dalam } \\
\text { Al-Qur'an }\end{array}$} & Jml. \\
\hline 1. & Al-Insan & Al-Alaq : 2 & |خَلَقََ الإنْسَانَ & 65 \\
\hline 2. & Al-Nas & Al-Nas : 1 & 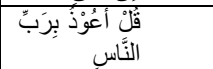 & 241 \\
\hline 3. & Al-Ins & $\begin{array}{l}\text { Al-A'raf : } \\
38\end{array}$ & 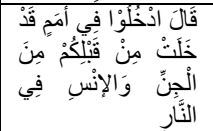 & 18 \\
\hline 4. & Unas & $\begin{array}{l}\text { Al-A'raf : } \\
82\end{array}$ & 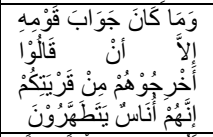 & 5 \\
\hline 5. & Anasiy & $\begin{array}{l}\text { Al- } \\
\text { Furqan : } 49\end{array}$ & 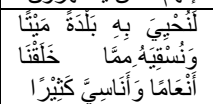 & 1 \\
\hline 6. & Insiy & $\begin{array}{l}\text { Maryam } \\
26\end{array}$ & 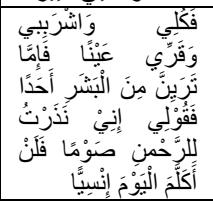 & 1 \\
\hline $\mathbf{J} \mathbf{u}$ & n I a h & & & 331 \\
\hline
\end{tabular}

Secara morfologis, asal kata $\mathrm{al}$ insan ini diperselisihkan. Segolongan ahli bahasa Arab berpendapat, bahwa kata al-insan berasal dari kata nasiyayansa yang berarti lupa. Alasan yang dipergunakan, karena bentuk tashgir dari kata insan adalah unaisiyan yang dapat diartikan bahwa manusia telah melupakan janjinya pada Tuhan. Hal ini bersandar pada perkataan Ibn 'Abbas.

Pendapat lain menyatakan bahwa asal kata al-insan adalah insiyan yang berakar kata ins yang berarti sesuatu yang tampak dan jinak. Pendapat ini menolak pendapat pertama dengan mengatakan huruf ya yang terdapat dalam kata unaisiyan merupakan tambahan, seperti halnya huruf $y a$ dalam kata ruwaijil yang merupakan tasghir dari kata rajul. Pendapat lain mengatakan bahwa asal kata insan adalah nasa-yanusu yang bermakna 'bergoncang'.
Apabila pendapat tersebut dilihat berdasarkan relevansi makna masingmasing kata tersebut (nasiya, ins dan nasa) dengan kata insan, maka pendapat kedua dipandang lebih kuat. Sebab, akar kata ins sendiri yang berarti sesuatu yang tampak dan jinak, makna ini relevan dengan sifat dan fisik manusia.

Makna pertama sesuatu yang tampak ditemukan konteksnya ketika al-Qur'an sering menggunakan kata tersebut untuk menghadapkannya dengan kata jin yang berarti makhluk halus atau tidak tampak. Misalnya digunakan dalam Q.S. al-Zariyat ayat 56:

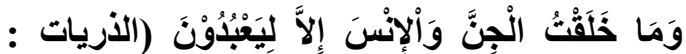
(56

"Dan Aku tidak menciptakan jin dan manusia melainkan supaya mereka menyembah-Ku”.

Sedangkan makna jinak relevan dengan makna kejiwaan seperti keramahan, kesenangan dan pengetahuan. Hal ini terlihat dari kata kerja yang terbentuk anisa-ya'nisu, anusa-ya'nusu, anasa-yanisu yang berarti ramah, suka; kata anasa yu'nisu yang berarti menjadi jinak, meraswa sesuatu, melihat, mendengar dan mengetahui.

Jika dilihat dari bentuknya, kata insan berpola fi'lan, pola tak beraturan (suma'iy) yang serarti dengan pola fa'alan, pola yang beraturan (qiyasy) dan mengandung konotasi intensitas. Apabila pengertian ini dikaitkan dengan makna etimologinya, maka dapat dikatakan bahwa kata insan mengandung konsep manusia sebagai makhluk yang memiliki keramahan dan kemampuan mengetahui yang sangat tinggi, atau dalam ungkapan lain, manusia merupakan makhluk kultural dan sosial. 
Konsep manusia sebagai makhluk kultural terlihat dalam pernyataan al-Qur'an bahwa manusia dilengkapi dengan sarana pengetahuan berupa pendengaran, penglihatan, dan budi sehingga mereka dapat memperoleh pengetahuan meskipun dilahirkan dalam keadaan tidak tahu sama sekali seperti dikemukakan dalam Q.S. an-Nahl : 78.

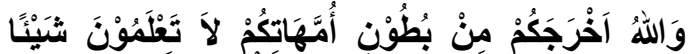

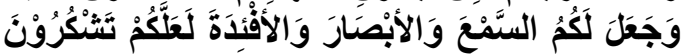
(النحل : (78)

"Dan Allah mengeluarkan kamu dari perut ibumu dalam keadaan tidak mengetahui sesuatu apapun, dan Dia memberi kamu pendengaran, penglihatan dan hati, agar kamu bersyukur."

Sedangkan konsep manusia sebagai makhluk sosial ini dipertegas dengan beberapa pernyataan al-Qur'an yang menegaskan tentang kejadian manusia dalam berbagai suku dan bangsa dan dimaksudkan agar mereka membentuk pergaulan hidup bersama (QS. al-Hujurat :13), saling membantu dalam kebaikan (QS. al-Maidah : 2), dan penegasan al-Qur'an tentang kebahagiaan manusia yang terkait dengan hubungan manusia dengan sesamanya (QS. Ali Imran : 112). Ayatayat tersebut adalah:

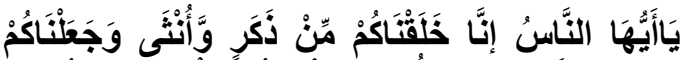

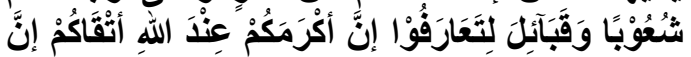

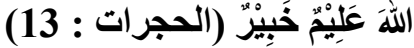

"Hai manusia, sesungguhnya Kami menciptakan kamu dari seorang lakilaki dan seorang perempuan dan menjadikan kamu berbangsa-bangsa dan bersuku-suku supaya kamu saling mengenal. Sesungguhnya orang yang paling mulia di antara kamu di sisi Allah ialah orang yang paling bertakwa di antara kamu. Sesungguhnya Allah
Maha Mengetahui lagi Maha Mengenal".

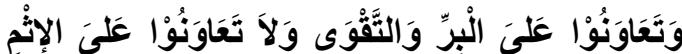

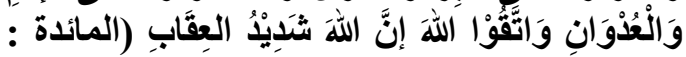
(3

“... Dan tolong menolonglah kamu dalam (mengerjakan) kebajikan dan takwa, dan jangan tolong menolong dalam berbuat dosa dan pelanggaran. Dan bertakwalah kamu kepada Allah, sesungguhnya Allah amat berat siksaNya".

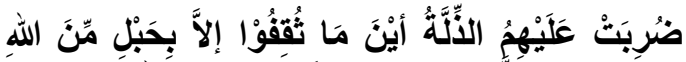

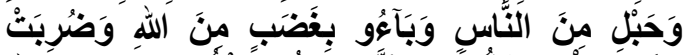

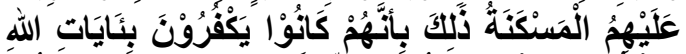

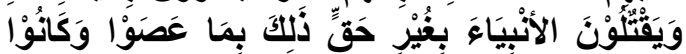

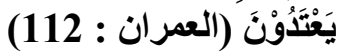

"Mereka diliputi kehinaan di mana saja mereka berada, kecuali jika mereka berpegang kepada tali (agama) Allah dan tali (perjanjian) dengan manusia, dan mereka kembali mendapat kemurkaan dari Allah dan mereka diliputi kerendahan. Yang demikian itu karena mereka kafir kepada ayat-ayat Allah dan membunuh para nabi tanpa alasan yang benar. Yang demikian itu disebabkan mereka durhaka dan melampaui batas".

\section{b) al-Basyar}

Dalam al-Qur'an, untuk makna manusia selain kata al-insan dipergunakan kata basyar. Al-Basyar berasal dari huruf $b a$, syin dan $r a$ yang berarti nampaknya sesuatu dengan baik dan indah. Dari makna tersebut terbentuk kata karja basyara yang berarti gembira, menggembirakan, memperhatikan dan mengurus sesuatu.

Dalam al-Qur'an, kata-kata yang berakar huruf $b-s y-r$ digunakan sebanyak 123 kali, yang pada umumnya bermakna kegembiraan, 37 kali bermakna manusia, dan dua kali dalam 
arti hubungan seksual. Menurut alRaghib, kata basyar adalah jamak dari kata basyarat yang berarti kulit. Manusia disebut basyar karena kulit manusia tampak berbeda dengan kulit makhluk lainnya. Kata ini dalam alQur'an secara khusus merujuk kepada tubuh dan bentuk lahiriah manusia.

Bertolak dari pendapat di atas, maka dapat disimpulkan bahwa istilah basyar menunjukan makna manusia pada aspek hakikatnya sebagai pribadi yang kongkrit, dengan menekankan aspek lahiriah manusia

\section{c) Banu Adam dan Zurriyat Adam.}

Istilah banu adam dan zuriyat adam merujuk kepada pengertian manusia karena adanya kaitan dengan nama Adam yang memberi kesan historis dalam konsep manusia, bahwa manusia berasal dari satu sumber dan satu darah, walaupun mereka tersebar dalam berbagai warna kulit, ras dan bangsa.

\section{Kedudukan dan Tugas Manusia}

Kedudukan manusia menurut Islam terbagi pada dua, yaitu sebagai 'abullah dan khalifah. Al-Qur'an telah menjelaskan eksistensi manusia sebagai ' $a b d$ atau hamba Allah ini dalam klausa liya' buduni Q.S. al-Zariyat 56 yang berbunyi :

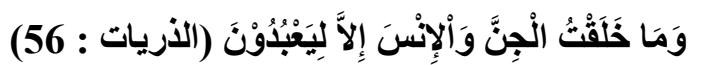

"Dan Aku tidak menciptakan jin dan manusia melainkan supaya mereka menyembah-Ku”.

Kata abd sendiri dalam Al-Qur'an pertamakali ditemukan dalam Q.S. al-Alaq : 10, kemudian dalam bentuk kata kerja ditemukan dalam QS. al-Fatihah : 5. Dari dua penggunaan kata 'abd tersebut, terlihat bahwa konsep yang terkandung meliputi dua aspek, yaitu subjek yang menyembah yaitu manusia dan objek yang disembah.
Pendapat para ulama beragam dalam merumumuskan makna ibadat secara istilah. Ibnu Karsir memberikan definisi ibadat dengan menunjuk sifatnya sebagai perbuatan yang menghimpun rasa kecintaan, penyerahan diri yang sempurna dari seorang hamba kepada Tuhan dan rasa khawatir yang mendalam terhadap penolakan Tuhan. Rasyid Ridha mengemukakan bahwa ibadat adalah kesadaran jiwa akan keagungan yang tidak diketahui sumbernya. Kekuatan, hakikat dan wujud sumber tersebut tak terjangkau oleh manusia. Senada dengan pendapat ini Muhamad Syaltout mengemukakan pengertian yang sama bahwa ibadat adalah kesadaran akan adanya kekuasaan yang tak terbatas. Oleh karenanya tanpa kesadaran tersebut ibadat tidak akan terwujud.

Dari beberapa pengertian di atas, dapat diambil kesimpulan bahwa kata 'abd mengandung pengertian ibadah dalam makna penyerahan diri manusia pada hukum-hukum Allah swt. yang menciptakannya. Dengan kata 'abd, Allah swt. ingin menunjukkan salah satu kedudukan manusia sebagai hamba Allah yang mengemban tugas-tugas peribadahan.

Sedangkan mengenai kedudukan manusia sebagai khalifah dapat kita temukan dalam QS. al-Fatir : 39 yang berbunyi:

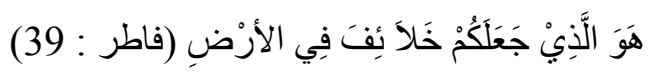

"Dia-lah yang menjadikan kamu khalifahkhalifah di muka bumi...".

Ayat tersebut memberikan penegasan terhadap informasi yang terkandung dalam ayat-ayat sebelumnya. Kalau ayat sebelumnya menjelaskan bahwa Allah swt mengetahui apa yang tidak terlihat oleh manusia, maka ayat ini menjelaskan Allah yang menjadikan manusia sebagai khalifah fi al-ardh.

Pengertian khalifah jika dilihat dari akar katanya berasal dari kata khalafa, yang berarti menggantikan tempat 
seseorang sepeninggalnya, karena itu khalif atau khalifah berarti seorang pengganti. Dengan inilah kata khulufa dan khalaif sebagai bentuk jamak dari kata khalifah telah digunakan dalam al-Qur'an.

Dalam kaitannya dengan kedudukan manusia sebagai khalifah fi al-ardh menurut Ensiklopedi Islam, bahwa khalifah itu berarti wakil, pengganti atau duta Tuhan di muka bumi; pengganti nabi Muhammad saw dalam fungsinya sebagai kepala pemerintahan, bahkan lebih jauh khalifatu fi al-ardh digambarkan sebagai kedudukan yang kudus, yaitu zill al-Allah fi al-ardh (bayang-bayang Allah di permukaan bumi).

Evidensi semua pengertian di atas, mengisyaratkan hal yang sama bahwa kata khalifah bermakna seseorang yang menggantikan yang lainnya, hanya saja di sini terdapat perbedaan yang cukup tajam tentang siapa yang digantikannya. Dalam hal ini Shalih Abdullah mengklasifikasikan kepada tiga pendapat. Pertama, pendapat yang mengatakan bahwa manusia merupakan spesies yang menggantikan spesies lain yang pernah lebih dahulu hidup di bumi. Kedua, pendapat yang menyatakan bahwa istilah khalifah dipakai untuk merujuk kepada kelompok manusia yang menggantikan kelompok manusia yang lain. Ketiga, pendapat yang menyatakan bahwa khalifah bukanlah sekedar menunjuk pengertian seorang mengganti atau mengikuti yang lain, namun lebih jauh adalah pengganti Allah.

Memahami perbedaan pendapat di atas, dibawah ini dikemukakan gambaran al-Qur'an.

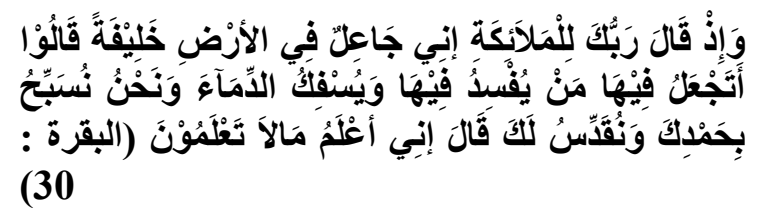

"Ingatlah ketika Tuhanmu berfirman kepada para malaikat: "Sesungguhnya Aku hendak menjadikan seorang khalifah di muka bumi". Mereka berkata:
"Mengapa Engkau hendak menjadikan (khalifah) di bumi itu orang yang akan membuat kerusakan padanya dan menumpahkan darah, padahal kami senantiasa bertasbih dengan memuji Engkau dan mensucikan Engkau?" Tuhan berfirman: "Sesungguhnya Aku mengetahui apa yang tidak kamu ketahui".

Jika melihat bagaimana hubungan manusia dengan Allah swt seperti digambarkan surat al-Baqarah 30 di atas, antara yang Mencipta dan yang dicipta, jelas bahwa penunjukan istilah khalifah lebih cenderung pada makna pengganti Allah. Dalam pengertian bahwa manusia mempunyai beban normatif untuk menuruti apa yang dikehendaki oleh Allah swt.

Dari pernyataan-pernyataan di atas, dapat ditarik kesimpulan bahwa pengertian khalifah sebagai duta atau wakil Tuhan di muka bumi merujuk pada pengertian individual yang dapat dimiliki oleh setiap umat manusia. Semua manusia berhak mendapat predikat yang sama, hanya saja kualifikasi ke-khalifah-annya akan ditunjukkan oleh sejauh mana hasil optimalisasi potensi kemanusiaan manusia tersebut.

Pada tahap struktural, al-Qur'an menyebut manusia sebagai nafs, dari ego, ke- $A k u$-an yang terbentuk dari unsur jasad, hayat dan ruh. Sedangkan dalam tahap fungsional menurut As'arie, al-Qur'an menyebut manusia sebagai 'abd dan dengan khalifah. Maka esensi manusia sebagai 'abd Allah, adalah ketaatan, ketundukan dan kepatuhan kepada Sang Pencipta. Sedangkan khalifah esensinya adalah kebebasan dan kreatifitas dalam upaya pembentukan kebudayaan, yang dalam konteks antropologi merupakan suatu proses perwujudan eksistensi manusia.

Kehadiran konsep khalifah, dalam hal ini tidak lantas dipertentangkan dengan konsep ' $a b d$, sebab keduanya berada dalam mainstream pemikiran yang sama. 
Menarik interpretasi Tobroni dan Samsul Arifin, fungsi manusia sebagai ' $a b d$, khalifah dalam konteks lebih makro, atau minimal dalam paradigma tauhid, keduanya tidak dipandang sebagai kesatuan terpisah, tapi memerlukan hubungan dialektik yang akan mengantarkan manusia kepada puncak eksistensi kemanusiaannya.

Dua tugas pokok di atas, haruslah merupakan paduan interaktif dan dialektis yang saling mempengaruhi dan saling mendukung, sehingga tercipta pribadi yang utuh dan sempurna dalam mengaktualisasikan nilai-nilai dalam kerangka trilogi hubungan harmonisdinamis, antara manusia dengan Tuhannya, antara manusia dengan masyarakat, dan lingkungan alam sekitarnya. Jika hal tersebut dilakukan, maka substansi kedudukan manusia sebagai khalifah dan 'abdullah dengan sendirinya akan terjelaskan.

\section{Potensi Manusia}

Secara kategorikal, potensi yang dimiliki manusia terdiri dari dua bagian. Bagian pertama, potensi yang inhern secara langsung dalam diri manusia, yaitu fitrah, kesatuan ruh dan jasad, kemampuan berkehendak dan potensi akal. Bagian kedua, perlengkapan yang mendukung potensi pertama di atas, yaitu alam semesta dan petunjuk hidup berupa agama.

Pertama, karakteristik manusia dalam al-Qur'an adalah fitrah. Kata fitrah dalam istilah Arab berarti berasal kejadian, kesucian dan agama yang benar. Fitrah dengan arti agama yang benar atau agama Allah adalah arti yang dihubungkan dengan al-Qur'an dalam QS. al-Rum: 30 yang berbunyi:

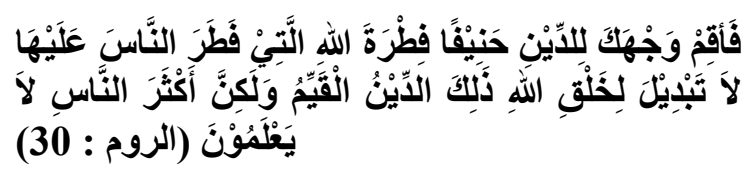

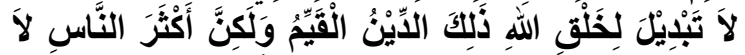
يَعْلَمُونَنَ (الروم :
"Maka hadapkanlah wajahmu dengan lurus kepada agama (Allah); (tetaplah atas) fitrah Allah yang telah menciptakan manusia menurut fitrah itu. Tidak ada perubahan pada fitrah Allah. (Itulah) agama yang lurus; tetapi kebanyakan manusia tidak mengetahui”.

Sedangkan pengertian fitrah yang berarti kesucian, terdapat dalam hadits yang menyebutkan semua bayi terlahir dalam keadaan fitrah, dalam keadaan suci dan oleh kedua orang tuanya dijadikan sebagai pemeluk Kristen, Yahudi dan Nasrani. Sementara fitrah dengan arti asal kejadian bersinonim dengan kata ibda dan khalq. Fitrah manusia dalam asal kejadiannya sebagaimana diciptakan Allah, menurut ajaran Islam adalah bebas dari noda dan dosa seperti bayi yang baru lahir dari perut ibunya.

Fitrah dalam arti asal kejadian ini juga dihubungkan dengan pernyataan seluruh manusia sewaktu di alam barzah yang mengakui ketuhanan, atau menurut Erich Fromm yang dikutif oleh Dawam Rahardjo, bahwa setelah manusia diciptakan, manusia mengadakan 'kesepakatan' dengan Tuhan (primordial covenant), dengan bahasa ilmiahempirisnya, kecenderungan asli atau fitrah manusia adalah menyembah Tuhan (beragama). Ketika manusia mencari makna hidup, maka kecenderungan mereka adalah menemukan Tuhan Yang Maha Esa, hal ini mendapat justifikasi al-Qur'an dalam surat al-'Araf ayat 172 yang berbunyi:

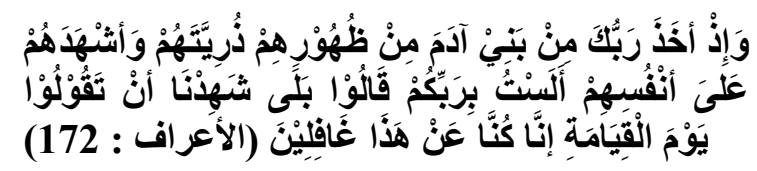

"Dan (ingatlah), ketika Tuhanmu mengeluarkan keturunan anak-anak Adam dari sulbi mereka dan Allah mengambil kesaksian terhadap jiwa mereka (seraya berfirman): "Bukankah Aku ini Tuhanmu?" Mereka menjawab: "Betul 
(Engkau Tuhan kami), kami menjadi saksi". (Kami lakukan yang demikian itu) agar di hari kiamat kamu tidak mengatakan: "Sesungguhnya kami (bani Adam) adalah orang-orang yang lengah terhadap ini (keesaan Tuhan)".

Dari beberapa pengertian fitrah di atas, menurut penulis ketiga-tiganya tidaklah berbeda, fitrah dalam pengertian umum selain ia terbebas dari noda dan dosa karena faktor warisan yang berbeda dengan konsep antropologi Kristen yang didasarkan atas konsep dosa waris, fitrah dipahami sebagai potensi bercorak keagamaan yang menyebabkan manusia mempunyai kecenderungan kuat terhadap kebaikan (hanif).

Menurut Ibn Taimiyah, pengertian fitrah tidak hanya terbatas pada makna tersebut saja, lebih jauh bahwa potensi fitrah tidak terbatas pada potensi yang bersifat keagamaan semata, tetapi juga mengandung tiga daya kekuatan, yaitu daya intelek (quwwah al-aql), yaitu potensi dasar yang dimiliki manusia untuk membedakan mana yang baik dan mana yang buruk, daya ofensif (kuwwah alsahwah), yaitu potensi dasar yang dimiliki manusia untuk menginduksi objek-objek yang menyenangkan dan bermanfaat, daya defensif (quwwah al-gadhab), yaitu potensi dasar yang dapat menghindarkan manusia dari segala perbuatan yang membahayakan bagi dirinya.

Karena fitrah merupakan potensi dasar perkembangan manusia yang dibawa sejak lahir dan merupakan pusat dasar dalam bertindak, yang berkembang secara menyeluruh dan bersifat dinamis-responsif terhadap lingkungan, menyebabkan potensi fitrah memegang posisi sentral dalam pengembangan kualitas manusia di masa depan.

Kedua, karakteristik manusia dalam al-Qur'an adalah jasad dan ruh dalam manusia. Jasad atau al-Jism merupakan bagian raga atau badan manusia yang berasal dari tanah. Sering dipandang sebagai pusat kemunculan kebutuhankebutuhan kepuasan semata, seperti kebutuhan biologis akan minum, makan, dan kebutuhan seksual.

Karena esensinya seperti itu, jasad kadang dipandang rendah, padahal dalam Islam menurut Fattah Jalal, tubuh merupakan tabiat manusia yang harus diperhatikan, karena tubuh atau jasad dapat membantu seseorang dalam menjalankan tugas kemanusiaannya.

Sedangkan ruh, secara harfiah berarti angin, nafs, merupakan hakikat diri manusia yang dengannya manusia dapat hidup dan mengetahui segala sesuatu. Ruh berarti juga zat murni yang hidup. Menurut Syafi'i Ma'arif, karena ruh inilah manusia memiliki kemampuan penalaran, intuisi, kebijakan dan kecerdasan.

Dari pernyataan di atas, terakumulasi bahwa manusia bukanlah sekedar makhluk berdaging dengan kebutuhan ragawinya ataupun makhluk spiritual semata, tapi manusia merupakan makhluk hasil perpaduan interaksi ruh dan jasad. Keterpaduan keduanya akan menunjukkan manusia yang sesungguhnya. Hakikat manusia dalam konteks ini adalah adanya interaksi seimbang antara ruh dan jasad dalam menciptakan kehidupan. Ia tidak bebas menyantuni kebutuhan biologisnya, karena ia bukanlah binatang, dan ia pun tidak bebas menyantuni kebutuhan rohaninya, karena ia bukanlah malaikat. Tapi karena model dan pola keseimbangan itulah, substansi manusia menjadi terwujud.

Ketiga, yang membedakan manusia dengan makhluk lainnya adalah kemampuan berkehendak (free well) dalam menentukan prilaku kehidupannya. Hal ini didasarkan pada surat al-Kahfi ayat 29 yang berbunyi:

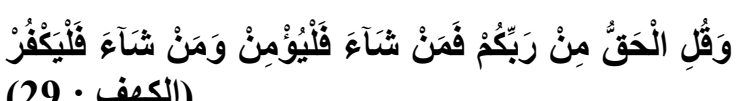
(الكهف : 29 (29)

"Dan katakanlah: "Kebenaran itu
datangnya dari
barangsiapa yang ingin (beriman) 
hendaklah ia beriman, dan barangsiapa yang ingin (kafir) biarlah ia kafir".

Ayat di atas menegaskan bahwa manusia memiliki kesadaran berkehendak untuk menerima atau menolak tentang keimanannya kepada Allah swt. Manusia mempunyai kehendak bebas dan membuatnya mampu melakukan seleksi terhadapelemen-elemen yang bakal berinteraksi dengan fitrah-nya.

Keempat, karakteristik manusia adalah akal. Di dalam al-Qur'an, banyak ayat yang menerangkan fungsi akal dan dorongan untuk menggunakan akal sebagai alat untuk mengetahui dan bertindak. Amr seperti itu seringkali dinyatakan dalam lafadz 'aqala, faqiha, dabbara, tafakkara, dan tadzakkara. Kata 'aql yang dalam alQur'an tidak pernah muncul sebagai kata benda abstrak (mashdar) sama sekali, secara bahasa berarti mengikat (seperti 'iqal yang berarti ikat kepala). Akal berfungsi sebagai pengikat atau integrator ketiga kesadaran yang ada dalam diri manusia yaitu kognitif, afektif, konatif dan menghubungkannya dengan qalb. 'Aql merupakan fungsi qalb seperti dijelaskan dalam QS. Al-Hujarat ayat 7:

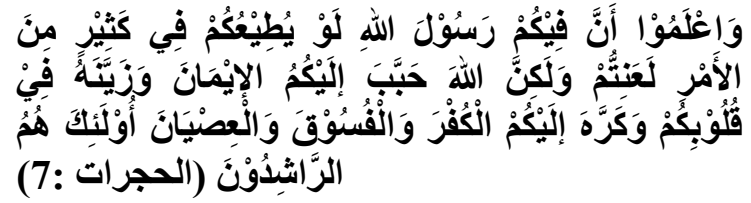

"Dan ketahuilah olehmu bahwa di kalangan kamu ada Rasulullah. Kalau ia menuruti (kemauan) kamu dalam beberapa urusan benar-benarkah kamu akan mendapat kesusahan tetapi Allah menjadikan kamu cinta kepada keimanan dan menjadikan iman itu indah dalam hatimu serta menjadikan kamu benci kepada kekafiran, kefasikan, dan kedurhakaan. Mereka itulah orang-orang yang mengikuti jalan yang lurus".

Dalam tatanan kehidupan, tidak kita sangsikan lagi bagaimana besarnya peranan akal. Adalah suatu ideologi di kalangan ilmuwan yang menyatakan bahwa seluruh bangunan dari ilmu pengetahuan manusia merupakan produk dari aktivitas akal. Dengan dilengkapi oleh refleksi ayat-ayat Tuhan, akal merupakan sebuah alat yang tepat untuk memahami pengetahuan, menemukan formula baru dari sebuah pengetahuan dalam bentuk wahyu verbal maupun non verbal.

Sebagai khalifah dan 'abdullah, manusia dituntut sebaik-baiknya untuk mempergunakan akal secara proporsional dan profesional sehingga secara otomatis membedakan dirinya dengan makhluk yang lainnya.

Empat atribut dan karakter yang telah dijelaskan di atas, sebagai potensi manusia sebagai khalifah dan 'abdullah pada koneks yang lebih makro dipandang sebagai ciri khas, atribut atau perangkat yang apabila fungsinya dioptimalisasikan akan mencapai kualitas manusia yang sempurna.

\section{Manusia Sebagai Makhluk Sosial}

Tidak diragukan lagi bahwa tujuan utama Islam adalah menegakkan suatu tatanan masyarakat yang adil yang berdasarkan etika. Apakah individu yang lebih penting dalam masyarakat adalah instrumen yang diperlukan di dalam penciptaannya atau sebaliknya, hal tersebut merupakan permasalahan akademis, karena tampaknya individu dan masyarakat tidak dapat dipisahkan. Tidak ada manusia sebagai individu tanpa adanya masyarakat. Oleh karenanya, menurut Fazlur Rahman, konsep amal perbuatan manusia yang ditawarkan al-Qur'an, senantiasa dan hanya berarti di dalam sebuah konteks sosial. Disinilah manusia dipertemukan pada dua sisi kesadaran. Pertama, kesadaran pada keberadaan (eksistensi) dari sendiri sebagai suatu diri (individualitas), dan Kedua, kesadaran pada keberadaan (eksistensi) bersama orang lain atau kebersamaan (sosialitas). Kedua kesadaran tersebut merupakan dua 
aspek yang berpadu sebagai suatu kesatuan, ibarat dua sisi mata uang, yang dapat dibedakan tetapi tak dapat dipisahkan. Aspek yang satu menunjang yang lain dan sebaliknya, yang memungkinkan manusia hidup secara manusiawi.

Kesadaran individualitas menekankan manusia sebagai individu yang otonom dalam mengantarkannya menjadi manusia yang beriman. Akan tetapi sulit dibantah bahwa dalam otonomi individu tidak memerlukan individu yang lain. Dalam keterhubungan (korelasi dan komunikasi), setiap individu di satu pihak menjadi semakin otonom, sedang di pihak lain mewujudkan penerimaan dan penghargaan atas otonomi individu yang lain. Dalam hubungan itu manusia menjalankan hakikat sosialitasnya, yang hanya mungkin terwujud apabila ada orang lain.

Untuk memahami konsep manusia sebagai makhluk sosial dalam perspektif Islam, terdapat dua konsep dasar manusia berkenaan dengan hakikat sosialitasnya. Pertama, istilah insan jika dibandingkan dengan istilah lain yang menunjukkan makna manusia (seperti basyar, banu adam dan zurriyat adam), mengandung makna konsep manusia sebagai makhluk yang memiliki sifat keramahan dan kemampuan mengetahui yang sangat tinggi, yang dengannya dapat dipahami sebagai makhluk kultural dan sosial.

Konsep manusia sebagai makhluk kultural terlihat dalam pernyataan alQur'an bahwa manusia dilengkapi dengan sarana pengetahuan pendengaran, penglihatan, dan budi sehingga mereka dapat memperoleh pengetahuan meskipun dilahirkan dalam keadaan tidak tahu sama sekali seperti dikemukakan oleh QS. anNahl : 78 .

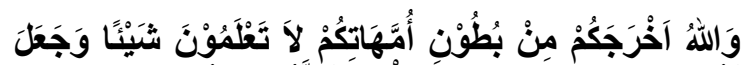

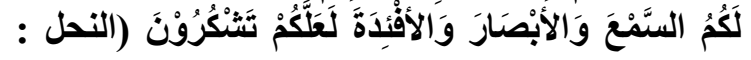
(78
"Dan Allah mengeluarkan kamu dari perut ibumu dalam keadaan tidak mengetahui sesuatu apapun, dan Dia memberi kamu pendengaran, penglihatan dan hati, agar kamu bersyukur."

Sedangkan konsep manusia sebagai makhluk sosial ini dipertegas dengan beberapa pernyataan al-Qur'an yang menegaskan tentang kejadian manusia dalam berbagai suku dan bangsa dan dimaksudkan agar mereka membentuk pergaulan hidup bersama (QS. al-Hujurat :13), saling membantu dalam kebaikan (QS. al-Maidah : 2), dan penegasan alQur'an tentang kebahagiaan manusia yang terkait dengan hubungan manusia dengan sesamanya (QS. Ali Imran : 112). Ayatayat tersebut adalah:

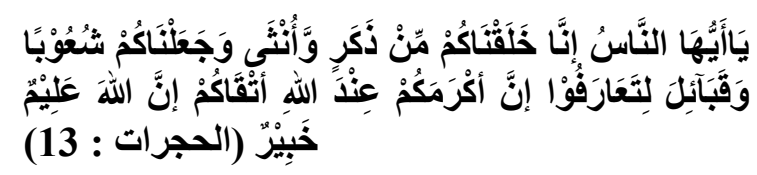

"Hai manusia, sesungguhnya Kami menciptakan kamu dari seorang laki-laki dan seorang perempuan dan menjadikan kamu berbangsa-bangsa dan bersuku-suku supaya kamu saling mengenal. Sesungguhnya orang yang paling mulia di antara kamu di sisi Allah ialah orang yang paling bertakwa di antara kamu. Sesungguhnya Allah Maha Mengetahui lagi Maha Mengenal”.

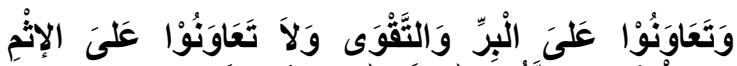

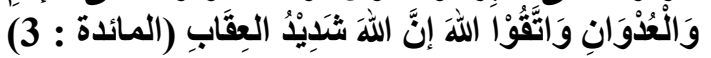
“... Dan tolong menolonglah kamu dalam (mengerjakan) kebajikan dan takwa, dan jangan tolong menolong dalam berbuat dosa dan pelanggaran. Dan bertakwalah kamu kepada Allah, sesungguhnya Allah amat berat siksa-Nya".

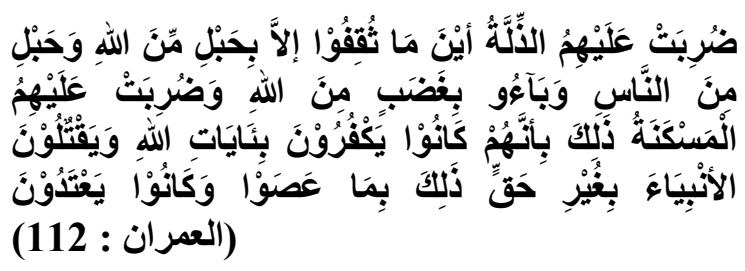


"Mereka diliputi kehinaan di mana saja mereka berada, kecuali jika mereka berpegang kepada tali (agama) Allah dan tali (perjanjian) dengan manusia, dan mereka kembali mendapat kemurkaan dari Allah dan mereka diliputi kerendahan. Yang demikian itu karena mereka kafir kepada ayat-ayat Allah dan membunuh para nabi tanpa alasan yang benar. Yang demikian itu disebabkan mereka durhaka dan melampaui batas".

Kedua, Jika dibanding dengan fungsi manusia sebagai 'abdullah, maka fungsi manusia sebagai khalifah lebih menekankan peran manusia sebagai makhluk sosial dalam menginternalisasikan tugas kebudayaan yang berciri kreatif pada kehidupannya, agar selalu dapat menciptakan sesuatu yang baru sesuai dengan kebutuhan perkembangan dan pertumbuhan masyarakat.

Tugas ini diemban manusia karena manusia dipandang mempunyai kemampuan konseptual dengan watak keharusan eksperimen berkesinambungan sampai menunjukkan kemakmuran dan kesejahteraan hidup di muka bumi. Dalam hal ini, syahminan Zaini menyatakan bahwa sebagai khalifah, manusia bertugas mensyukuri segala nikmat itu sesuai dengan kehendak Sang Pemberi Nikmat, yakni dengan berkarya kreatif, memakmurkan bumi, membudayakan alam atau mengkulturkan natur.

Tugas terakhir ini, pada dasarnya secara implisit menggambarkan konsep metafisis-antropologis-nya Islam tentang manusia dengan pandangan yang positif dan konstruktif. Dalam Islam, manusia tidak hanya ditempatkan secara simplikatif sebagai bagian sistematik dari realitas makro kosmos, lebih jauh Islam menuntut peran kreatif manusia untuk mengelola alam sebagai sumber daya material (material resource) sebagai pengejawantahan tugas kemanusiaan di muka bumi.

Kedua konsep dasar tersebut telah meletakkan dasar yang kuat bahwa pandangan tentang manusia menurut alQur'an bukan saja diposisikan sebagai makhluk yang individualistik, tetapi juga sebagai makhluk sosial. Oleh karenanya, secara rinci, al-Qur'an juga mengemukakan beberapa penegasan normatif mengenai bagaimana mewujudkan kebersamaan (sosialitasnya) sebagai bagian dari hakikat manusia, di antaranya adalah sebagai berikut:

1. Kewajiban berbuat baik, menghormati dan menghargai orang lain, menyerukan kebaikan dan mencegah kejahatan seperti dikemukakan dalam QS. An-Nisa : 36, Ali Imran : 104 dan 110, at-Taubah : 71, yaitu:

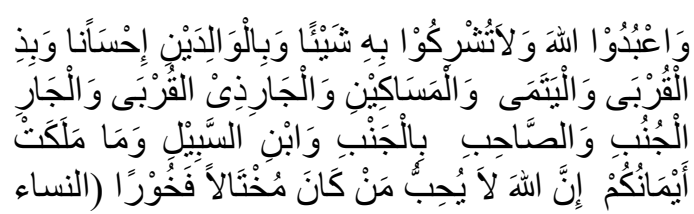

(36:

"Sembahlah Allah dan janganlah kamu mempersekutukan-Nya dengan sesuatupun. Dan berbuat baiklah kepada dua orang ibu-bapak, karibkerabat, anak-anak yatim, orang-orang miskin, tetangga yang dekat dan tetangga yang jauh, teman sejawat, ibnu sabil dan hamba sahayamu. Sesungguhnya Allah tidak menyukai orang-orang yang sombong dan membangga-banggakan diri”.

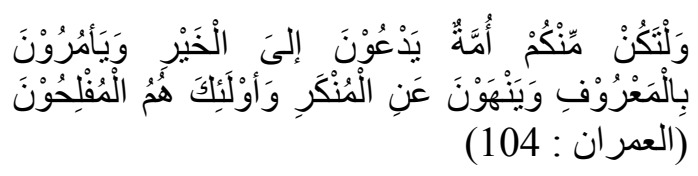

"Dan hendaklah ada di antara kamu segolongan umat yang menyeru kepada kebajikan, menyuruh kepada yang ma'ruf dan mencegah dari yang munkar, merekalah orang-orang yang beruntung". 


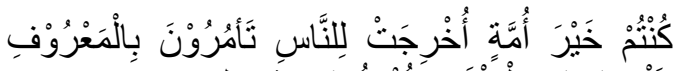

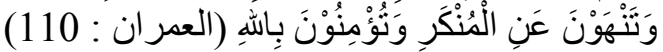

"Kamu adalah umat yang terbaik yang dilahirkan untuk manusia, menyuruh kepada yang ma'ruf, dan mencegah dari yang munkar, dan beriman kepda Allah,...".

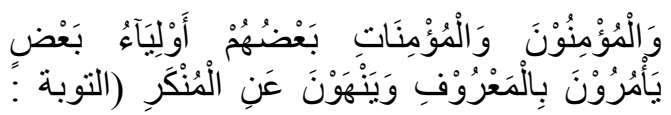

"Dan orang-orang yang beriman, lelaki dan perempuan, sebahagian mereka (adalah) menjadi penolong bagi sebahagian yang lain. Mereka menyuruh (mengerjakan) yang ma'ruf, mencegah dari yang munkar,..".

2. Kewajiban manusia untuk saling tolong menolong seperti dikemukakan dalam QS. AlMa'idah : 2:

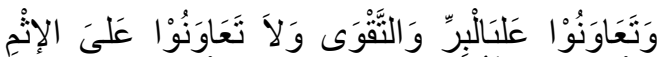

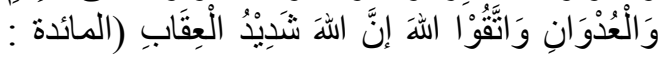

"Dan tolong-menolonglah kamu dalam (mengerjakan) kebajikan dan takwa, dan jangan tolong menolong dalam berbuat dosa dan pelanggaran. Dan bertakwalah kamu kepada Allah, sesungguhnya Allah amat berat siksa-Nya".

3. Kewajiban manusia untuk berbuat adil seperti dikemukakan dalam QS. An-Nisa : 58 dan 135, QS. As-Syura : 38, QS. al-An'am : 119, yaitu:

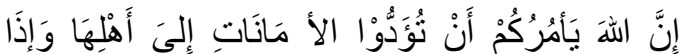

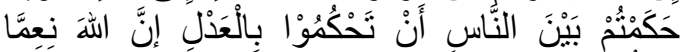

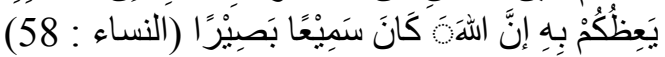

"Sesungguhnya Allah menyuruh kamu menyampaikan amanat kepada yang berhak menerimanya, dan (menyuruh kamu) apabila menetapkan hukum di antara manusia supaya kamu menetapkan dengan adil. Sesungguhnya Allah memberi pengajaran yang sebaikbaiknya kepadamu. Sesungguhnya Allah Maha Mendengar lagi Maha Melihat".

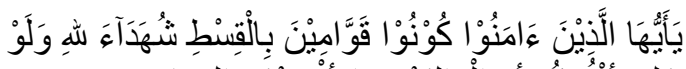

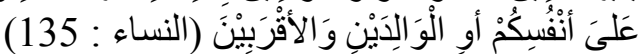

"Wahai orang-orang yang beriman, jadilah kamu orang-orang yang benarbenar penegak keadilan, menjadi saksi karena Allah biarpun terhadap dirimu sendiri atau ibu bapa dan kaum kerabatmu”.

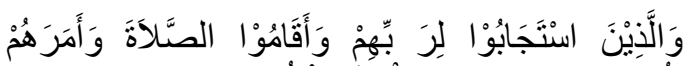

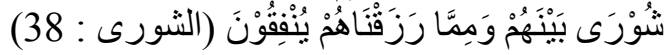

"Dan (bagi) orang-orang yang menerima (mematuhi) seruan Tuahannya dan mendirikan shalat, seda ng urusan mereka (diputuskan) dengan musyawarat antara mereka; dan mereka menafkahkan sebagian dari rezki yang Kami berikan kepada mereka”.

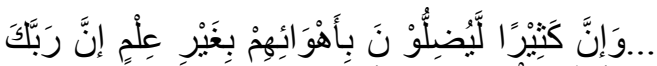

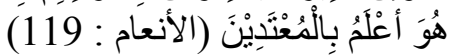

"Dan sesungguhnya kebanyakan (dari manusia) benar-benar hendak menyesatkan (orang lain) dengan bawa hawa nafsu mereka tanpa pengetahuan. Sesungguhnya Tuhanmu, Dia-lah yang lebih mengetahui orang-orang yang melampaui batas".

4. Kewajiban manusia untuk tidak berprasangka, mencari-cari kesalahan orang lain, saling menggunjing, dan saling mencaci maki seperti dikemukakan dalam QS. al-Hujarat : 12, yaitu:

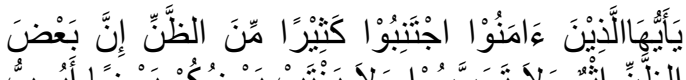

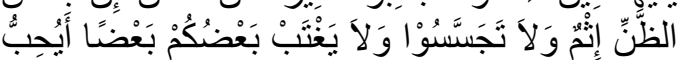




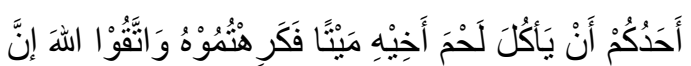

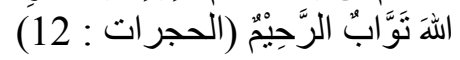

"Hai orang-orang yang beriman, jauhilah kebanyakan dari prasangka, sesungguhnya sebagian prasangka itu adalah dosa janganlah kamu mencaricari kesalahan orang lain dan jaganlah sebahagian kamu menggunjing sebahagian yang lain. Sukakah salah seorang di antara kamu memakan daging saudaranya yang sudah mati? Maka tentulah kamu merasa jijik kepadanya. Dan bertakwalah kepada Allah. Sesungguhnya Allah Maha Penerima taubat lagi Maha Penyayang”.

5. Kewajiban manusia untuk menghargai hak hidup orang lain dengan tidak saling membunuh seperti dikemukakan dalam QS. al-Maidah : 32, QS. AlAn'am : 151, yaitu:

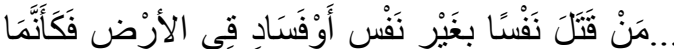

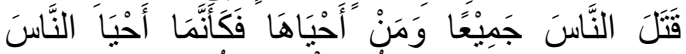

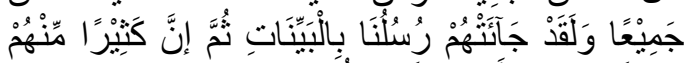

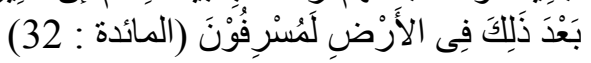

“... barangsiapa yang membunuh seoran

$g$ manusia, bukan karena orang itu (membunuh) orang lain, atau bukan karena berbuat kerusakan di muka bumi, maka seakan-akan dia telah membunuh manusia seluruhnya. Dan barangsiapa yang memelihara kehidupan manusia, maka seolah-olah dia telah memelihara kehidupan manusia semuanya. Dan sesungguhnya telah datang kepada mereka rasul-rasul Kami dengan (membawa) keteranganketerangan yang jelas, kamudian banyak di antara mereka sesudah itu sungguh-sungguh melampaui batas dalam berbuat kerusakan di muka bumi".

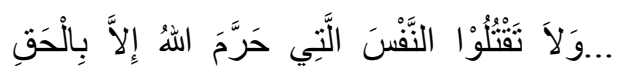

(الأنعام : (151)

“... dan janganlah kamu membunuh jiwa yang diharamkan Allah (membunuhnya) melainkan dengan sesuatu (sebab) yang benar...".

6. Pada level sosial-politik al-Qur'an menguatkan unit kekeluargaan paling dasar dan masyarakat muslim yang lebih besar dengan meniadakan rasa kesukuan. Semua kaum muslimin dinyatakan bersaudara; Bersama-sama mereka tidak dapat digoyahkan sebagai sebuah bangunan yang kokoh, seperti dikemukakan QS. Al-Hujarat : 10, ashShaf : 4, yaitu:

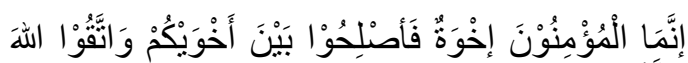

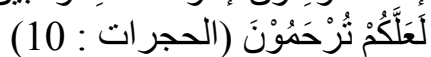

"Sesungguhnya orang-orang mukmin adalah bersaudara karena itu damaikanlah antara kedua saudaramu dan bertakwalah kepada Allah supaya kamu mendapat rahmat".

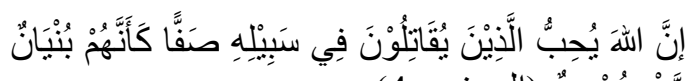

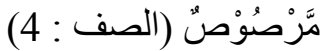

"Sesungguhnya Allah menyukai orang-orang yang berperang di jalan-Nya dalam barisan yang teratur seakan-akan mereka seperti satu bangunan yang tersusun kokoh".

7. Al-Qur'an menyuruh kaum muslimin untuk menegakkan prinsip-prinsip syura dalam melaksanakan urusan bersama seperti dikemukakan dalam QS. Asy-Syura : 38, yaitu:

8.

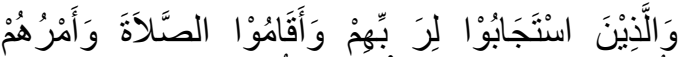

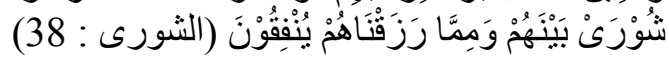

"Dan (bagi) orang-orang yang menerima (mematuhi) seruan Tuhannya dan mendirikan shalat, sedang urusan mereka (diputuskan) 
dengan musyawarat antara mereka; dan mereka menafkahkan sebagian dari rezki yang Kami berikan kepada mereka".

9. Al-Qur'an menyuruh kaum muslimin untuk menegakkan tata sosial moral yang egalitarian dengan melakukan reformasi terhadap dunia. Untuk tujuan itulah, al-Qur'an menyerukan jihad sebagaimana dikemukakan dalam QS. Al-Hajj : 41, QS. At-Taubah : 41, yaitu:

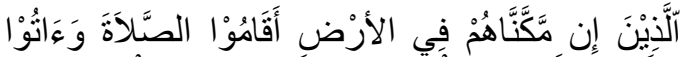

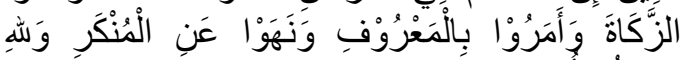

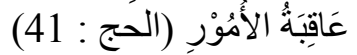

“(yaitu) orang-orang yang jika Kami teguhkan kedudukan mereka di muka bumi, niscaya mereka mendirikan sembahyang, menunaikan zakat, menyuruh berbuat yang ma'ruf dan mencegah dari perbuatan yang munkar; dan kepada Allah-lah kembali segala urusan."

\section{DAFTAR PUSTAKA}

Muin Salim, Konsepsi Politik dalam alQur'an, Jakarta: LSIK \& Rajawali Press, 1994, hlm. 81

Chatib Thoha dan Syukur Nc., Priyanto, Reformasi Filsafat Pendidikan Islam, Pustaka Pelajar, Semarang, Cet. ke-1, 1996, hlm. 123.

Disarikan oleh Muin Salim, dalam Fiqh Siyasah: Konsepsi Kekuasaan Politik dalam Al-Qur'an, Raja Grafindo Persada, Jakarta, 1994, hlm. 331 dengan sumber dari Fuaad 'Abd. AlBa'qi, Mu'jam al-Mufahras li alfazh al-Qur'an al-Karim, cet. ke-4, Dar al-Ma'arif, Bairut, 1994, hlm. 119120

Abu al-Fadhl Jamal al-Din Muhammad bin Mukram Ibn Manzhur, Lisan al'Arab, Mishr: Dar Shadr \& Dar Bairut, 1969, hlm. 11
Kata jinn secara etimologis bermakna tertutup. Dari akar kata ini berasal kata jannat yang berarti surga yakni pahala yang tertutup dari mata manusia; atau janin yakni anak dalam kandungan ibunya yang tidak dapat dilihat. Lois Ma'luf, al-Munjid fi al-Lughat wa alAdab wa al-Ulum, Bairut, Kotolikiyat, t.t., hlm. 19

Lois Ma'luf, op. cit., hlm. 39

Abu Qasim Abu Husain bin Muhammad al-Asfahani al-Raghib, al-Mufradat fi Gharib al-Qur'an, Mushthafa alBab al-Halabi, Mishr, 1961, hlm. 47

Ibid., hlm. 85

Qamaruddin Khan, Tentang Teori Politik Islam, Bandung, Pustaka, 1987, hlm. 35

Shalih, op. cit., hlm. 68

Lihat Tobroni dan Samsul Arifin, Islam, Pluralisme Budaya dan Politik Refleksi Teologi untuk Aksi dalam keberagamaan dan Pendidikan, Yogyakarta: Si Press, 1994, hlm. 154. Anonimous, Ensiklopedi, op. cit., hlm. 20 Dawam Rahardjo, Intelektual, Intelegensia dan Prilaku Politik Bangsa, Risalah Cendikiawan Muslim, Bandung, Mizan, 1993, hlm. 39

Juhaya S. Praja, Ulumul Qur'an, No. 7. II/1990, hlm. 75-76

Shalih, op. cit., hlm. 85

Abdul Fattah Jalal, Min Ushulil Tarbawiyah Islamiyah, terj. AsasAsas Pendidikan Islam, Bandung Diponegoro, 1988, hlm. 56

Syafi'i Ma'arif, Al-Qur'an Realitas Sosial dan Limbo Sejarah; Sebuah Refleksi, Bandung: Pustaka, 1985, hlm. 144.

Van Peursen, Tubuh, Jiwa, Ruh: Sebuah Pengantar Filsafat Manusia, Yogyakarta: Gunung Mulia, 1991, hlm. 197.

Abdul Munir Mulkhan, Paradigma Intelektual Islam, Yogyakarta: SI Press, 1993, hlm. 197.

Fazlur Rahman, Mazor Themes of the Qur'an, terj. Tema Pokok al-Qur'an, Bandung: Pustaka, 1995, hlm. 54 
Hakikat Manusia Menurut Islam (Isop Syafe'i)

Hadari Nawawi, Hakikat Manusia

Menurut Islam, Surabaya: Al-Ikhlas, 1993, hlm. 156-157. 